\title{
Effect of different levels of amino acid and vitamins in starter period of broilers on performance and antibody titer production
}

\section{Rashidi H., Gheisari A.}

\author{
${ }^{1}$ Department of Animal Science, Islamic Azad University, Isfahan (Khorasgan), Branch, Isfahan, ${ }^{2}$ Isfahan \\ Agricultural and Natural Resources Research and Education Center, Areeo, 8174835117, Isfahan, Iran \\ Corresponding author ${ }^{*}$ : rashiddaneh@yahoo.com; Tel: +98 9161925241
}

Journal of Livestock Science (ISSN online 2277-6214) 10: 126-131

Received on 30/9/2019; Accepted on 12/11/2019

doi. 10.33259/JLivestSci.2019.126-131

\begin{abstract}
This study was conducted to evaluate the effect of vitamin and amino acid levels in starter period on growth performance and immune responses of broilers. A total of 585 one-day-old broilers (Ross 308) were randomly assigned to nine experimental diets, each diet had five replicates of thirteen broilers. Daily feed intake, body weight, and daily weight gain were not significantly affected by amino acid and vitamin levels in each rearing period $(\mathrm{P}>0.05)$. In overall rearing period the lowest feed conversion ratio was obtained by $85 \%$ vitamin level $(\mathrm{P}<0.05)$. Also, the significant effect was observed between interaction effect of amino acid and vitamin levels $(\mathrm{P}<0.05)$. The antibody titer against Newcastle Disease and Avian Influenza Viruses were not significantly affected by amino acid and vitamin levels $(\mathrm{P}>0.05)$. Although, in starter period performance indices by $85 \%$ amino acid and vitamin levels were insignificantly higher than other levels. In grower period, performance indices were insignificantly increased by $115 \%$ amino acid level and $85 \%$ vitamin level ( $\mathrm{P}>0.05)$. The $100 \%$ amino acid and $85 \%$ vitamin level in finisher period insignificantly increased performance indices $(\mathrm{P}>0.05)$. In overall rearing period, performance indices were improved by $100 \%$ amino acid and $85 \%$ vitamin level $(\mathrm{P}>0.0 \%)$. These results indicated that performance indices was improved by $100 \%$ amino acid and $85 \%$ vitamin level $(\mathrm{P}>0.05)$, but immune responses were not significantly affected by amino acids and vitamin levels $(\mathrm{P}>0.05)$.
\end{abstract}

Keywords: Broiler; Performance; Amino acid; Vitamin; Immunity 


\section{Introduction}

Methionine is one of the essential amino acid with at least four main roles; first participation protein synthesis; second, as a glutathione precursor, which reduces reaction oxygen and protects cell from oxidative stress; third, methionine needs for synthesis polyamines such as spermine and spermidine which participate in nucleus and cell division events; fourth, methionine as an important methyl group donor for methylation reactions of DNA and other molecules. (Rubin et al. 2007). Methionine and lysine are the two amino acids that have proven immune regulatory role (Bouyeh, 2012). Some studies reported that methionine constructively affects the immune system, improving both cellular and humoral immune responses (Shini and Bryden, 2005). Methionine supplementation has useful effects on the immune system under various catabolic conditions (Mirzaaghatabar et al. 2011). Some researchers reported that dietary levels of lysine and methionine more than recommended amounts for broilers may increase body weight (El-Wahab et al. 2015; Zhai et al. 2016), body weight gain (Si et al. 2001; El-Wahab et al. 2015), feed conversion ratio, breast meat yield (Si et al. 2001; Bouyeh and Gevorgyan, 2011; Zhai et al. 2016; Walls 1999), abdominal fat deposition, fat content of the breast and thigh muscles carcass efficiency (Bouyeh and Gevorgyan, 2011). Also, recent studies related to broilers shown that methionine and lysine supplementation can stimulate the immune responses of broilers (Mirzaaghatabar et al. 2011; Faluyi et al. 2015; Saleh et al. 2018). Also, previous studies have shown that methionine deficiency can change the relative proportion of T lymphocyte subset (Wu et al. 2012), and inhibit the propagation and differentiation of bursal lymphocytes (Wu et al. 2013).

Therefore, the ratio of macronutrients has a main effect on performance and body composition of broilers after post-hatch (Collin et al, 2003; Swennen et al. 2007) and macronutrients changes will decrease their performance (Kidd et al. 2004). So, the content of crude protein, amino acids, energy, macro and micro elements in pre-starter diet can affect the growth and development of broiler chickens.

Threonine is a third limiting amino acid for broilers and they cannot synthesize it in their body (Ayasan et al. 2009). It was reported that threonine deficiency resulted in decreasing application of total sulfur amino acid and lysine. Because the concentration of threonine is high in Gamma globulin, it affects the immune function (Azzam et al., 2011a, b). Ciftci and Ceylan (2004) reported that threonine requirements of broilers at various age is available. Threonine serves as a variety of function in body; for instance, plays an important role in feather synthesis, precursor of glycine and serine and it is important for mucin production and intestinal health (Najafi et al., 2017).

The aim of the study was to evaluate the levels of methionine, lysine and threonine requirements and vitamin supplement in starter periods on performance, Newcastle and Influenza Disease of broiler chicks.

\section{Materials and methods}

\section{Experimental design and bird husbandry}

The experiment was conducted according to methods approved by the animal care and use committee of the Department of Animal Science, Islamic Azad University, Isfahan (Khorasgan) Branch, Isfahan, Iran. A total of 585 one-day-old broilers (Ross 308) were randomly assigned to nine experimental diets consisting of five replicates of thirteen broilers each pen. All the birds had ad-libitum access to feed and water throughout the experiment. At day one the temperature was set at $33^{\circ} \mathrm{C}$, and then it was reduced by $2.5^{\circ} \mathrm{C}$ each week until reaching $24^{\circ} \mathrm{C}$.

Experimental diets

Nine experimental diets were formulated in this experiment to contain 85,100 and $115 \%$ amino acid, and 85,199 and $115 \%$ vitamin requirement of Ross 308 in starter (Table 1), grower and finisher (Table 2) periods. The amino acids and vitamins were provided from Evonik Degussa and ADISSEO, respectively. The broilers received the experimental diet from zero to 10 days of age, and after that broilers received common diets. The experimental diets were as follow: A) Basal diet $+100 \%$ amino acid $+100 \%$ vitamin; B) Basal diet $+100 \%$ amino acid $+115 \%$ vitamin; C) Basal diet+100\% amino acid+85\% vitamin; D) Basal diet+115\% amino acid+100\% vitamin; E) Basal diet $+115 \%$ amino acid $+115 \%$ vitamin; F) Basal diet $+115 \%$ amino acid $+85 \%$ vitamin; G) Basal diet $+85 \%$ amino acid $+100 \%$ vitamin; H) Basal diet+85\% amino acid+ $115 \%$ vitamin; I) Basal diet+85\% amino acid+85\% vitamin.

Performance measurement

The performance parameters such as body weight (BW), average daily gain (ADG), daily feed intake (DFI) and feed conversion ratio (FCR) were measured at the end of each rearing period.

Immune response

At 32 days of age two broilers per replicate were randomly selected and blood sample was taken from the brachial vein and centrifuged to obtain serum. Antibody titers against Newcastle and Influenza Viruses were measured using Hemagglutination Inhibition (HI) test (Jahanian, 2009). 


\section{Statistical analysis}

The obtained results were analyzed using one-way ANOVA of SAS software (SAS, 2009), significant differences $(\mathrm{P}<0.05)$, among treatment means were determined using the Duncan multiple range test.

Table 1 Ingredients and nutrient composition of the experimental starter $(0-10 \mathrm{~d})$ diet

\begin{tabular}{|c|c|c|c|c|c|c|c|c|c|}
\hline \multirow{2}{*}{ Item $(\%)$} & \multicolumn{3}{|c|}{$100 \%$ Amino acid } & \multicolumn{3}{|c|}{$115 \%$ Amino acid } & \multicolumn{3}{|c|}{$85 \%$ Amino acid } \\
\hline & $\mathrm{A}$ & $\mathrm{B}$ & $\mathrm{C}$ & $\mathrm{D}$ & $\mathrm{E}$ & $\mathrm{F}$ & $\mathrm{G}$ & $\mathrm{H}$ & I \\
\hline Corn & 49 & 49 & 49 & 48.5 & 48.5 & 48.5 & 49.5 & 49.5 & 49.5 \\
\hline Soybean meal & 38 & 38 & 38 & 38.1 & 38.1 & 38.1 & 37.9 & 37.9 & 37.9 \\
\hline Wheat & 8 & 8 & 8 & 8 & 8 & 8 & 8 & 8 & 8 \\
\hline Soybean oil & 0.97 & 0.97 & 0.97 & 0.97 & 0.97 & 0.97 & 0.97 & 0.97 & 0.97 \\
\hline $\mathrm{CaCo}_{3}$ & 1.5 & 1.5 & 1.5 & 1.5 & 1.5 & 1.5 & 1.5 & 1.5 & 1.5 \\
\hline Monocalcium phosphate & 1.2 & 1.2 & 1.2 & 1.2 & 1.2 & 1.2 & 1.2 & 1.2 & 1.2 \\
\hline Salt & 0.18 & 0.18 & 0.18 & 0.13 & 0.13 & 0.13 & 0.21 & 0.21 & 0.21 \\
\hline Choline chloride & 0.15 & 0.15 & 0.15 & 0.15 & 0.15 & 0.15 & 0.15 & 0.15 & 0.15 \\
\hline L-Lysine & 0.25 & 0.25 & 0.25 & 0.42 & 0.42 & 0.42 & 0.08 & 0.08 & 0.08 \\
\hline DL-Methionine & 0.34 & 0.34 & 0.34 & 0.43 & 0.43 & 0.43 & 0.23 & 0.23 & 0.23 \\
\hline L-Threonine & 0.1 & 0.1 & 0.1 & 0.19 & 0.19 & 0.19 & 0.01 & 0.01 & 0.01 \\
\hline Phytaze & 0.05 & 0.05 & 0.05 & 0.05 & 0.05 & 0.05 & 0.05 & 0.05 & 0.05 \\
\hline $\mathrm{NaHCO}_{3}$ & 0.08 & 0.08 & 0.08 & 0.17 & 0.17 & 0.17 & 0.02 & 0.02 & 0.02 \\
\hline Vitamin premix $^{1}$ & 0.1 & 0.115 & 0.85 & 0.1 & 0.11 & 0.85 & 0.1 & 0.11 & 0.85 \\
\hline Mineral premix $^{2}$ & 0.1 & 0.1 & 0.1 & 0.1 & 0.1 & 0.1 & 0.1 & 0.1 & 0.1 \\
\hline \multicolumn{10}{|l|}{ Calculated nutrients } \\
\hline $\begin{array}{ll}\text { Metabolizable } & \text { energy } \\
(\mathrm{Kcal} / \mathrm{Kg}) & \end{array}$ & 2850 & 2850 & 2850 & 2850 & 2850 & 2850 & 2850 & 2850 & 2850 \\
\hline Crude protein $(\%)$ & 22 & 22 & 22 & 22 & 22 & 22 & 22 & 22 & 22 \\
\hline Lysine (\%) & 1.35 & 1.35 & 1.35 & 1.48 & 1.48 & 1.48 & 1.21 & 1.21 & 1.21 \\
\hline Methionine+Cysteine $(\%)$ & 1 & 1 & 1 & 1.1 & 1.1 & 1.1 & 0.9 & 0.9 & 0.9 \\
\hline Threonine $(\%)$ & 0.9 & 0.9 & 0.9 & 1 & 1 & 1 & 0.8 & 0.8 & 0.8 \\
\hline Calcium (\%) & 1 & 1 & 1 & 1 & 1 & 1 & 1 & 1 & 1 \\
\hline Available phosphorous (\%) & 0.48 & 0.48 & 0.48 & 0.48 & 0.48 & 0.48 & 0.48 & 0.48 & 0.48 \\
\hline
\end{tabular}

${ }^{1}$ Provided per kilogram of diet: Vitamin A 12000; Cholecalciferol 5000 IU; Vitamin E 45 IU; Vitamin K 2.4 mg; Thiamin 2.6 mg; Riboflavin 6.6 mg; Pantothenic acid $25 \mathrm{mg}$; Niacin $55 \mathrm{mg}$; Cholin chloride $500 \mathrm{mg}$; Biotin $0.1 \mathrm{mg}$; Folic acid $1.5 \mathrm{mg}$; Pyridoxine $5.5 \mathrm{mg}$; Vitamin B12 0.015 $\mathrm{mg}$; BHT $1 \mathrm{mg}$.

Table 2 Ingredients and nutrient composition of the grower (11-24 d) and finisher (25-40d) diets

\begin{tabular}{|l|l|l|}
\hline Item $(\%)$ & Grower & Finisher \\
\hline Corn & 57.3 & 57.3 \\
\hline Soybean meal & 36.5 & 30 \\
\hline Soybean oil & 2.4 & 2 \\
\hline CaCo $_{3}$ & 1.6 & 1.5 \\
\hline Monocalcium phosphate & 1.1 & 0.9 \\
\hline Salt & 0.36 & 0.35 \\
\hline Choline chloride & 0.1 & 0.1 \\
\hline L-Lysine & 0.1 & 0.14 \\
\hline DL-Methionine & 0.28 & 0.24 \\
\hline L-Threonine & 0.05 & 0.03 \\
\hline Phytase & 0.005 & 0.005 \\
\hline Vitamin premix & 0.1 & 0.1 \\
\hline Mineral premix & \\
\hline Calculated nutrients & 0.1 & 0.1 \\
\hline $\begin{array}{l}\text { Metabolizable energy } \\
\text { (Kcal/Kg) }\end{array}$ & 2900 & 2950 \\
\hline Crude protein (\%) & 20.7 & 18.44 \\
\hline Lysine (\%) & 1.18 & 1.05 \\
\hline Methionine+Cysteine(\%) & 0.92 & 0.82 \\
\hline Threonine (\%) & 0.82 & 0.72 \\
\hline Calcium (\%) & 0.95 & 0.85 \\
\hline Available phosphorous (\%) & 0.475 & 0.42 \\
\hline
\end{tabular}

${ }^{1}$ Provided per kilogram of diet: Vitamin A 12000; Cholecalciferol 5000 IU; Vitamin E 45 IU; Vitamin K 2.4 mg; Thiamin 2.6 mg; Riboflavin 6.6 mg; Pantothenic acid $25 \mathrm{mg}$; Niacin $55 \mathrm{mg}$; Cholin chloride $500 \mathrm{mg}$; Biotin $0.1 \mathrm{mg}$; Folic acid $1.5 \mathrm{mg}$; Pyridoxine $5.5 \mathrm{mg}$; Vitamin B12 0.015 mg; BHT 1 mg. ${ }^{2}$ Provided per kilogram of diet: Fe 50 mg; Zn 85 mg; Mn 90mg; I 1 mg; Cu 10 mg; Se 0.25 mg. 


\section{Results}

\section{Growth performance}

As shown in Table 3, in different rearing periods dietary amino acid and vitamin levels had no effect on daily feed intake (DFI), body weight $(\mathrm{BW})$, daily weight gain (DWG), feed conversion (FCR) of broilers $(\mathrm{P}<0.05)$. Also, there was no significant interaction effect on performance parameters of broilers at different rearing periods $(\mathrm{P}>0.05)$.

\section{Immune response}

As presented in Table 4, antibody titer production against Newcastle Disease and Avian Influenza were not significantly affected by different amino acid and vitamin levels $(\mathrm{P}>0.05)$. Also, there was no significant interaction effect of vitamin and amino acid levels on antibody titer production $(\mathrm{P}>0.05)$.

Table 3. Effect of amino acids and vitamins levels on performance of broilers

\begin{tabular}{|l|l|l|l|l|l|l|l|}
\hline \multirow{2}{*}{$1-10 \mathrm{~d}$} & \multicolumn{3}{|c|}{ Amino acid levels } & \multicolumn{3}{c|}{ Vitamin levels } & Interaction \\
\cline { 2 - 8 } & $85 \%$ & $100 \%$ & $115 \%$ & $85 \%$ & $100 \%$ & $115 \%$ & AA $\times$ Vit \\
\hline DFI & $27.47 \pm 0.31$ & $26.61 \pm 0.34$ & $26.97 \pm 0.22$ & $27.03 \pm 0.29$ & $26.89 \pm 0.30$ & $27.13 \pm 0.33$ & NS \\
\hline BW & $245 \pm 3.20$ & $243 \pm 2.77$ & $244 \pm 2.16$ & $245 \pm 2.02$ & $243 \pm 3.16$ & $243 \pm 2.89$ & NS \\
\hline DWG & $20.19 \pm 0.31$ & $20.0 \pm 0.28$ & $20.10 \pm 0.21$ & $20.25 \pm 0.19$ & $20.03 \pm 0.31$ & $20.01 \pm 0.28$ & NS \\
\hline FCR & $1.36 \pm 0.01$ & $1.33 \pm 0.01$ & $1.34 \pm 0.01$ & $1.33 \pm 0.01$ & $1.34 \pm 0.01$ & $1.36 \pm 0.01$ & NS \\
\hline $11-24 \mathrm{~d}$ & & & & & & & \\
\hline DFI & $72.21 \pm 0.84$ & $72.88 \pm 0.76$ & $74.45 \pm 0.68$ & $72.99 \pm 0.82$ & $72.95 \pm 0.73$ & $73.60 \pm 0.86$ & NS \\
\hline BW & $846 \pm 7.53$ & $857 \pm 10.22$ & $865 \pm 5.99$ & $865 \pm 7.42$ & $850 \pm 8.54$ & $853 \pm 8.57$ & NS \\
\hline DWG & $42.91 \pm 0.48$ & $43.87 \pm 0.62$ & $44.38 \pm 0.41$ & $44.27 \pm 0.48$ & $43.32 \pm 0.56$ & $43.57 \pm 0.53$ & NS \\
\hline FCR & $1.68 \pm 0.02$ & $1.66 \pm 0.02$ & $1.68 \pm 0.02$ & $1.65 \pm 0.01$ & $1.69 \pm 0.02$ & $1.69 \pm 0.02$ & NS \\
\hline $25-40 d$ & & & & & & & \\
\hline DFI & $147.16 \pm 0.97$ & $147.08 \pm 2.03$ & $149.60 \pm 1.68$ & $148.96 \pm 1.33$ & $146.72 \pm 2.21$ & $148.17 \pm 1.13$ & NS \\
\hline BW & $2165 \pm 19.1$ & $2199 \pm 31.42$ & $2184 \pm 29.70$ & $2228 \pm 23.67$ & $2156 \pm 32.1$ & $2165 \pm 21.64$ & NS \\
\hline DWG & $82.47 \pm 1.44$ & $83.92 \pm 1.56$ & $82.42 \pm 1.83$ & $85.15 \pm 1.33$ & $81.67 \pm 1.93$ & $81.99 \pm 1.38$ & NS \\
\hline FCR & $1.79 \pm 0.03$ & $1.76 \pm 0.02$ & $1.82 \pm 0.03$ & $1.75 \pm 0.02$ & $1.81 \pm 0.04$ & $1.81 \pm 0.02$ & NS \\
\hline $1-40 d$ & & & & & & & \\
\hline DFI & $90.29 \pm 0.43$ & $90.10 \pm 1.00$ & $91.58 \pm 0.79$ & $90.89 \pm 0.71$ & $90.05 \pm 0.97$ & $91.06 \pm 0.66$ & NS \\
\hline DWG & $53.05 \pm 0.47$ & $53.92 \pm 0.79$ & $53.53 \pm 0.74$ & $54.62 \pm 0.59$ & $52.84 \pm 0.80$ & $53.05 \pm 0.54$ & NS \\
\hline FCR & $1.70 \pm 0.01$ & $1.67 \pm 0.02$ & $1.71 \pm 0.02$ & $1.66^{\mathrm{b}} \pm 0.01$ & $1.71^{\mathrm{ab}} \pm 0.02$ & $1.72 \pm 0.02$ & NS \\
\hline
\end{tabular}

Table 4. Effect of amino acids and vitamins levels antibody production against Newcastle Disease and Avian Influenza Viruses $\left(\log _{2}\right)$

\begin{tabular}{|l|l|l|l|l|l|l|l|}
\hline \multirow{2}{*}{ Antibody response } & \multicolumn{3}{|c|}{ Amino acid levels } & \multicolumn{3}{c|}{ Vitamin levels } & $\begin{array}{c}\text { Interaction } \\
\text { AA } \times \text { Vit }\end{array}$ \\
\cline { 2 - 8 } & $85 \%$ & $100 \%$ & $115 \%$ & $85 \%$ & $100 \%$ & $115 \%$ & \\
\hline Newcastle Disease & $4.53 \pm 0.18$ & $4.77 \pm 0.16$ & $4.33 \pm 0.13$ & $4.50 \pm 0.19$ & $4.43 \pm 0.13$ & $4.70 \pm 0.16$ & NS \\
\hline Avian Influenza & $3.13 \pm 0.11$ & $3.10 \pm 0.12$ & $2.93 \pm 0.14$ & $2.93 \pm 0.12$ & $3.13 \pm 0.13$ & $3.10 \pm 0.12$ & NS \\
\hline
\end{tabular}

\section{Discussion}

\section{Performance}

Similarly, Sigolo et al (2019) observed that 10 and 20\% methionine surpluses did not affect broiler growth performance at starter, grower and overall rearing period. While, in finisher period $10 \%$ methionine and $20 \%$ lysine surplus increased average daily feed intake, average daily energy intake, average daily protein intake, and average daily gain. Wallis (1999) illustrated that feed intake of broilers significantly increased by increasing levels methionine. In agreement with these findings, Cengiz et al (2008) reported that a methionine surplus had no effect on growth performance of broilers, but the lysine surplus decreased the pre-slaughtered body weight. It was suggested that free synthetic amino acid should have higher availability than amino acids in intact proteins (Ciftci and Ceylan, 2004; Abbasi et al. 2014; Sigolo et al. 2017).

The results of Bouyeh and Gevorgyan (2011) are in contrast to recent findings, they showed that supplemental methionine and lysine in broilers diet improved feed conversion ratio. El-Wahab et al (2015) reported that additional methionine and lysine increased weight of broilers. The discrepancies between literatures might be 
due to the use of different experimental conditions. Li et al (2001) stated that nutritional shortage in early period after post-hatch development induced constant negative effect on body weight at the end of rearing period. According to obtained results, performance parameters of broilers were insignificantly improved by $85 \%$ vitamin level compare to other vitamin levels. It may conclude that vitamin premix used in poultry production provides more vitamin than minimum recommended levels (Maiorka et al. 2002; Rath et al. 2000).

\section{Immunity}

Increased haemagglutination inhibition (HI) antibody titre was gained by high levels of methionine, which is not in line with present study. Also, the IgG levels against Newcastle Disease Viruse was significantly increased $(\mathrm{P}<0.05)$ at high levels of methionine (Mirzaaghatabar et al. 2011). Swain and Johri (2000) reported that leukocyte migration and antibody titre was increased by methionine supplementation.

Bouyeh (2012) stated that methionine and lysine play role in antibody synthesis, so adequate amount of both are needed for immune system function. Sigolo et al (2019) found that immune responses against Newcastle Disease Viruses of broilers fed surplus lysine tended to increase.

\section{Conclusion}

In conclusion, amino acid and vitamin levels had no significant effect on performance parameters and Antibody titer production against Newcastle Disease and Avian Influenza Diseases. The 85\% vitamin level compare to other levels was optimum for growth performance in different rearing period and overall rearing period. Further research is needed to understand how amino acid and vitamin levels in starter period will affect the performance parameters and antibody titer production at the grower and finisher rearing periods.

\section{References}

1) Abbasi M, Mahdavi AH, Samie AH, Jahanian R, 2014. Effect of different levels of dietary crude protein and threonine on performance, humoral immune responses and intestinal morphology of broiler chicks. Brazilian Journal of Poultry Science 16: 35-44.

2) Ayasan T, Okan F, Hizli H, 2009. Threonine requirement of broiler from 22-42 days. International Journal of Poultry Science 8: 862-865.

3) Azzam MMM, Dong XY, Xie P, Wang C, Zou XT, 2011b. The effect of supplemental L-threonine on laying performance, serum free amino acids and immune function of laying hens under high temperature and high humidity environmental climates. Journal of Applied Poultry Research 20: 361-270.

4) Azzam MMM, Zou XT, Dong XY, Xie P, 2011a. Effect of supplemental L-threonine on mucin-2 gene expression and intestine mucosal immune and digestive enzymes activities of laying hens in environments with high temperature and humidity. Poultry Science 90: 2251-2256.

5) Bouyeh M, Gevorgyan OK, 2011. Influence of excess lysine and methionine on cholesterol, fat and performance of broiler chicks. Journal of Animal Veterinary Advances 10(12): 1546-1550.

6) Bouyeh M, Gevorgyan OK, 2011. Influence of excess lysine and methionine on cholesterol, fat and performance of broiler chicks. Journal of Animal Veterinary Advances 10(12): 1546-1550.

7) Bouyeh M, 2012. Effect of excess lysine and methionine on immune system and performance of broilers. Annals of Biological Science, 3(7): 3218-3224.

8) Bouyeh M, 2012. Effect of excess lysine and methionine on immune system and performance of broilers. Annals of Biological Research 3(7): 3218-3224.

9) Cengiz O, Onol AG, Sevim O, Oztur KM, Sari M, Daskiran M, 2008. Influence of excessive lysine and or methionine supplementation on growth performance and carcass traits in broiler chicks. Rev Med Vet 159(4): 230-236.

10) Ciftci I, Ceylan B, 2004. Effect of dietary threonine and crude protein on growth performance, carcass and meat composition of broiler chickens. British Poultry Science 45: 280-289.

11) Ciftci I, Ceylan M, 2004. Effects of dietary threonine and crude protein on growth performance, carcass and meat composition of broiler chickens. British Poultry Science 45(2): 280-289.

12) Collin A, Malheiros RD, Moraes VMB, Van ASP, Darras VM, Tauois M, 2003. Effects of dietary macronutrient content on energy metabolism and uncoupling protein mRNA expression in broiler chickens. British Journal Nutrition 90: 261-269.

13) El-Wahab AA, Aziza A, El-Adl M, 2015. Impact of dietary excess methionine and lysine with or without addition of L-carnitine on performance, blood lipid profile and litter quality in broilers. Asian Journal of Animal Veterinary Advances 10(5): 191-202. 
14) El-Wahab AA, Aziza A, El-Adl M, 2015. Impact of dietary excess methionine and lysine with or without addition of L-Carnithine on performance, blood lipid profile and litter quality in broilers. Asian Journal of Animal Veterinary Advances 10(5): 191-202.

15) Faluyi OB, Agbede JO, Adebayo IA, 2015. Growth performance and immunological response to Newcastle Disease Vaccinations of broiler chickens fed lysine supplemented diets. Journal of Veterinary Medicine and Animal Health 7(3): 77-84.

16) Jahanian R, 2009. Immunological responses as affected by dietary protein and arginine concentrations in starting broiler chicks. Poultry Science 88: 1818-1824.

17) Kidd MT, McDaniel CD, Branton SL, Miller ER, Boren BB, Fancher BI, 2004. Increasing amino acid density improves live performance and carcass yields of commercial broilers. Journal of Applied Poultry Research 13: 593-604.

18) Li Y, Yuan L, Yang X, Ni Y, Xia Y, Barth S, Grossman R, Zhao RQ, 2007. Effect of early feed restriction on myofibre types and expression of growth-related genes in the gastrocnemius muscle of crossbred broiler chickens. British Journal of Nutrition 98: 310-319.

19) Maiorka A, Laurentiz AC, Santin E, 2002. Dietary vitamin or mineral mix removal during the finisher period on broiler chicken performance. Journal of Applied Poultry Research 11: 121-126.

20) Mirzaaghatabar F, Saki AA, Zamani P, Aliarabi H, HematiMatin HR, 2011. Effect of different levels of diet methionine and metabolizable energy on broiler performance and immune system. Food and Agricultural Immunology 22(2): 93-103.

21) Mirzaaghatabar F, Saki AA, Zamani P, Aliarabi H, HematiMatin HR, 2011. Effect of different levels of diet methionine and metabolisable energy on broiler performance and immune system. Food and Agricultural Immunology 22(2): 93-103.

22) Najafi R, Ahmar R, Tazehkand GN, 2017. Effect of different dietary threonine levels on optimal growth performance and intestinal morphology in 1-14 days old Ross 308 broilers. Brazilian Journal of Poultry Science 19: 59-65.

23) Rath NC, Huff GR, Huff WE, 2000. Factors regulating bone maturity and strength in poultry. Poultry Science 79: 1024-1032.

24) Rubin LL, Canal CW, Ribeiro ALM, Kessler A, Silva I, Trevizan L, Viola T, Raber M, Goncalves TA, Kras R, 2007. Effects of methionine and arginine dietary levels on the immunity of broiler chickens submitted to immunological stimuli. Brazilian Journal of Poultry Science 9(4): 241-247.

25) Saleh AA, Ragab MM, Ahmed EAM, Abudabos AM, Ebeid TA, 2018. Effect of dietary zinc-methionine supplementation on growth performance, nutrient utilization, antioxidant properties and immune response in broiler chickens under high ambient temperature. Journal of Applied Animal Research 46(1): 820-827.

26) SAS Institute, 2009. SAS proprietary software, release 9.2. SAS Inst. Inc., Cary, NC.

27) Shini S, Li X, Bryden WL, 2005. Methionine requirement and cell-mediated immunity in chicks. British Journal of Nutrition 94: 746-752.

28) Si J, Fritts CA, Burham DJ, Waldroup PW, 2001. Relationship of dietary lysine level to the concentration of all essential amino acids in broiler diets. Poultry Science 80: 1472-1479.

29) Sigolo S, Deldar E, Seidavi A, Bouyeh M, Gallo A, Prandini A, 2019. Effects of dietary surpluses of methionine and lysine on growth performance, blood serum parameters, immune responses and carcass traits of broilers. Journal of Applied Animal Research 47(1): 146-153.

30) Swain BK, Johri TS, 2000. Effect of supplemental methionine, choline and their combinations on the performance and immune response of broilers. British Poultry Science 41: 83-88.

31) Swennen Q, Decuypere E, Buyse J, 2007. Implications of dietary macronutrients for growth and metabolism in broiler chickens. World's Poultry Science 63: 541-556.

32) Walls IR, 1999. Dietary supplements of methionine increase breast meat yield and decrease abdominal fat in growing broiler chickens. Australian Journal of Experimental Agriculture 39 (2): 131-141.

33) Wu B, Cui H, Peng X, Fang J, Liu XD, 2012. Effect of methionine deficiency on the thymus and the subsets and proliferation of peripheral blood T-cell, and serum IL-2 contents in broilers. Journal of Integrative Agriculture 11: 1009-1019.

34) Wu B, Cui H, Peng X, Fang J, Cui W, Liu XD, 2013. Pathology of bursa of fabricius in methionine deficient broiler chickens. Nutrients 5: 877-886.

35) Zhai W, Peebles ED, Schilling MW, Mercier Y, 2016. Effects of dietary lysine and methionine supplementation on Ross 708 male broilers from 21 to $42 \mathrm{~d}$ of age (1): growth performance, meat yield, and cost effectiveness. Journal of Applied Poultry Research 25: 197-211. 